\title{
Phytochemical Compounds and Antioxidant Activity in the Grain of Selected Faba Bean (Vicia faba) Genotypes
}

\author{
Soon-Jae Kwon $^{1 \dagger}$, Dong-Gun Kim ${ }^{1 \dagger}$, Jung Min Kim ${ }^{1}$, Kyung-Yun Kang ${ }^{2}$, Min-Kyu Lee ${ }^{1}$, Min Jeong Hong ${ }^{1}$, \\ Jin-Baek Kim', Seok Hyun Eom $^{3}$, Si-Yong Kang ${ }^{1}$, Bo-Keun Ha $^{4}$, Jaihyunk Ryu ${ }^{1,4}$. \\ ${ }^{1}$ Advanced Radiation Technology Institute, Korea Atomic Energy Research Institute, Jeongup 56212, Korea \\ ${ }^{2}$ Suncheon Research Center for Natural Medicines, Suncheon 57922, Korea \\ ${ }^{3}$ Department of Horticultural Biotechnology, College of Life Sciences, Kyung Hee University, Yongin 17104, Korea \\ ${ }^{4}$ Division of Plant Biotechnology, College of Agriculture and Life Science, Chonnam National University, Gwangju 61186, Korea
}

\begin{abstract}
The faba bean produces medicinally useful phenolic compounds naturally, and is also a good source of food and animal feed. This study quantified the functional compounds and antioxidant activities of five faba bean genotypes selected on the basis of their seed yield and L-dopa content. The highest total tannin content (TTC) and total proanthocyanidin content (TPAC) were observed in the PI252004 genotype and the lowest content in the PI366039 genotype. The total phenolics content (TPC) and total flavonoid content (TFC) of the PI430715 genotype were higher than those of the other genotypes. LC-MS analyses identified 22 different phenolic compounds in the faba bean genotypes. The most abundant proanthocyanidin compounds were prodelphinidin and catechin and the predominant flavonols and flavones were myricetin, quercetin, apigenin, kaempferol, and luteolin-free aglycones or glycosides. The TFC was correlated with ferric-reducing antioxidant power activity (FRAP) $(P \leq 0.05)$, Trolox equivalent antioxidant capacity (TEAC) $(P \leq 0.01)$, and DPPH radical scavenging activity $(P \leq 0.01)$. The results indicated that the PI430715 genotype contained the highest TPC and TFC and exhibited the highest FRAP, TEAC and DPPH radical scavenging activities. These results may help determine the optimal genotypes for breeding new cultivars of faba bean with potentially greater health benefits.
\end{abstract}

Keywords Antioxidants activities, Correlation analysis, Faba bean, Phenolic compounds

\section{INTRODUCTION}

The faba bean (Vicia faba L.) is one of the most important legume crops for human and animal consumption in many countries (Goyoaga et al. 2008), particularly for people in East Asia, Europe and Latin America (Adsule and Akpapunam 1996). The color of faba beans can vary from white to green, light brown, dark brown, purple and black (Shazali 1990; Ryu et al. 2017). Faba beans are rich in many nutrients such as protein, starch, dietary fiber and fatty acids (Goyoaga et al. 2008;
Crepon et al. 2010; Ryu et al. 2017) and also contain many functional phenolic and flavonoid compounds such as tannin, proanthocyanidins, L-3,4-dihydrophenylalanine (L-dopa), flavonols and flavones which possess antioxidant activity (Shetty et al. 2003; Baginsky et al. 2013; Siah et al. 2014; Boukhanouf et al. 2016). Phenolic compounds have the advantage of reducing the risk of hypertension, cancer and mutagenic activity and L-dopa compounds have anticancer properties and can be used to treat Parkinson's disease (Shetty et al. 2003; Oomah et al. 2011; Hu et al. 2015). The tannin content in the seed coat is

Received January 31, 2018; Revised February 20, 2018; Accepted February 22, 2018; Published March 1, 2018

*Corresponding author Jaihyunk Ryu, pain993300@sunchon.ac.kr, Tel: +82-62-530-2055, Fax: +82-62-530-2059

*Corresponding author Bo-Keun Ha, bkha@jnu.ac.kr, Tel: +82-62-530-2055, Fax: +82-62-530-2059

${ }^{\dagger}$ These authors contributed equally to this work. 
an important factor affecting the feed value of the grain, because it can adversely affect the metabolizable energy in the grain and the protein available for animals (Nozzolillo et al. 1989; Gunawardena et al. 2010; Kosinska et al. 2011). Tannins have also been considered as a healthpromoting component in foods and beverages (Baginsky et al. 2013; Siah et al. 2014).

To cultivate new crops in the natural environment, the yield, morphological characteristics and adaptability to the environment of the available genotypes need to be estimated (Agung and McDonald, 1998; Ryu et al. 2016, 2017). Identifying the phytochemical and antioxidant properties is a major factor when selecting cultivars in a breeding program (Hu et al. 2015; Ryu et al. 2016, 2017). Phytochemicals are biologically active chemical compounds that support many health benefits (Ito et al. 2013; Ryu et al. 2017) with high antioxidant activity in plants being considered most important (Baginsky et al. 2013; Chaieb et al. 2011; Boukhanouf et al. 2016). As the use of plants as foods and drugs has increased, research into their phytochemicals and antioxidant activity has also increased (Ryu et al. 2016). Assessing the phytochemical content is an important criterion for identifying new compounds of medicinal value and thus making the best use of naturally available materials (Takahashi et al. 2005; Majewska et al. 2011; Ryu et al. 2017). Legume crops have often been used therapeutically because they contain components with high functional potential (Ito et al. 2013; Ryu et al. 2017). In particular, phenolic and flavonoid compounds have been widely used in medicine, and as flavoring additives in the food industry (Majewska et al. 2011; Ryu et al. 2016).

Thus, the objective of the present study was to investigate and compare the physicochemical characteristics and antioxidant activity of selected faba bean genotypes to help determine which would be suitable for further study regarding their potential health benefits.

\section{MATERIALS AND METHODS}

\section{Plant materials and extraction}

Five faba bean genotypes (Fig. 1), selected on the basis of their seed yield, seed coat color, and L-dopa and linolenic acid contents (Ryu et al. 2017), were obtained
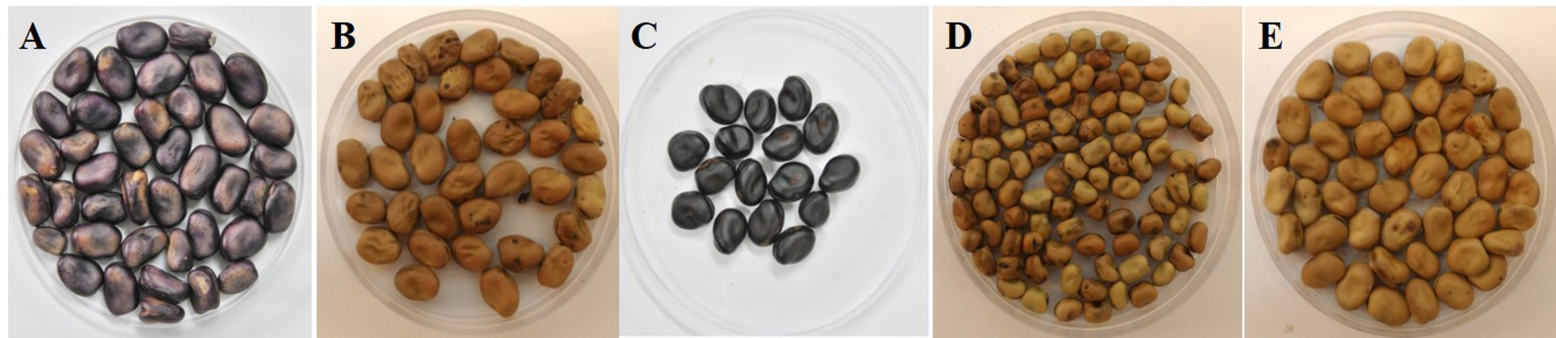

Fig. 1. Seed coat color profiles of five selected faba bean genotypes bred in Korea. (A) PI252004, (B) PI284345, (C) PI366039, (D) PI614810, (E) PI430715.

Table 1. Origin and phytochemical content of faba bean.

\begin{tabular}{|c|c|c|c|c|c|c|c|}
\hline No. & $\begin{array}{l}\text { Accession } \\
\text { number }\end{array}$ & Origin & $\begin{array}{l}\text { Seed coat } \\
\text { color }\end{array}$ & $\begin{array}{l}\text { Total tannin } \\
\text { content }(\mathrm{mg} / \mathrm{g})\end{array}$ & $\begin{array}{l}\text { Total flavonoid } \\
\text { content }(\mathrm{mg} / \mathrm{g})\end{array}$ & $\begin{array}{l}\text { Total phenolics } \\
\text { content }(\mathrm{mg} / \mathrm{g})\end{array}$ & $\begin{array}{c}\text { Total } \\
\text { proanthocyanidin } \\
\text { content }(\mathrm{mg} / \mathrm{g})\end{array}$ \\
\hline 1 & PI252004 & Turkey & Purple & $0.65 \pm 0.02 \mathrm{a}^{\mathrm{z})}$ & $10.41 \pm 0.77 b$ & $29.71 \pm 0.85 \mathrm{a}$ & $0.271 \pm 0.004 a$ \\
\hline 2 & PI284345 & Italy & Brown & $0.58 \pm 0.03 b$ & $9.98 \pm 0.86 b$ & $26.73 \pm 1.79 b$ & $0.182 \pm 0.006 \mathrm{~d}$ \\
\hline 3 & PI366039 & Argentina & Black & $0.21 \pm 0.01 d$ & $8.18 \pm 0.24 c$ & $24.82 \pm 1.04 \mathrm{c}$ & $0.162 \pm 0.010 \mathrm{e}$ \\
\hline 4 & PI614810 & USA & Brown & $0.41 \pm 0.01 \mathrm{c}$ & $10.01 \pm 0.64 b$ & $26.12 \pm 0.52 b$ & $0.201 \pm 0.001 \mathrm{c}$ \\
\hline 5 & PI430715 & Hungary & Brown & $0.58 \pm 0.06 b$ & $16.40 \pm 1.09 \mathrm{a}$ & $29.10 \pm 1.04 \mathrm{a}$ & $0.220 \pm 0.008 b$ \\
\hline
\end{tabular}

\footnotetext{
${ }^{\mathrm{z})}$ Different letters indicate a significant difference at the 0.05 probability level (Duncan's multiple range tests, $\mathrm{n}=3$ ).
} 
from the United States Department of Agriculture (Table 1). The color of the seeds was purple, brown or black. These lines were cultivated from 2014 to 2015 at the breeding farm of the Advanced Radiation Technology Institute at the Korean Atomic Energy Research Institute, Jeong-eup, Republic of Korea. For each of the five genotypes, the grains of the faba bean were harvested from three biological replicates. Extracts were taken from a $10 \mathrm{~g}$ grain sample using $50 \mathrm{~mL}$ of methanol for 24 hours. The extract samples were then used to determine total tannin content (TTC), total polyphenol content (TPC), total flavonoid content (TFC), total proanthocyanidin content (TPAC), Trolox equivalent antioxidant capacity (TEAC), ferric-reducing antioxidant power (FRAP), and 2, 2-diphenyl-1-picrylhydrazyl (DPPH) radical scavenging activity and analyzed using ultra-high performance liquid chromatography mass spectrometry (UPLC-MS).

\section{Total tannin content}

The TTC was determined using a modified vanillin-hydrochloric acid assay (Price et al. 1978). The absorbance level was measured at $500 \mathrm{~nm}$ using a UV-spectrophotometer (UV-1800, Shimadzu, Kyoto, Japan). Standard curves were used to express TTC as catechin equivalents.

\section{Total phenolic content}

The TPC was determined using a modified FolinCiocalteu colorimetric method (Ryu et al. 2016). Each extract $(0.2 \mathrm{~mL})$ was mixed thoroughly with $1.5 \mathrm{~mL}$ of Folin-Ciocalteu reagent $(20 \% \mathrm{v} / \mathrm{v})$. After adding $7 \%$ sodium carbonate $(4 \mathrm{~mL})$, the mixture was made up to 10 $\mathrm{mL}$ with double-distilled water. The mixture was then kept in the dark at room temperature for 90 minutes. The absorbance was measured at $760 \mathrm{~nm}$ using a UVspectrophotometer (UV-1800, Shimadzu, Kyoto, Japan). TPC was calculated using a calibration curve of tannic acid.

\section{Total flavonoid content}

The TFC of the grain of the faba bean was determined as described by Zhishen et al. (1999). Each extract sample $(0.2 \mathrm{~mL})$ was added to $4 \mathrm{~mL}$ of water in a flask then $0.3 \mathrm{~mL}$ of $5 \%$ sodium nitrite was added. The samples were allowed to stand for 5 minutes then $0.3 \mathrm{~mL}$ of $10 \%$ aluminum chloride was added. After adding $2 \mathrm{~mL}$ of sodium hydroxide, the mixture was made up to $10 \mathrm{~mL}$ with double-distilled water. The absorbance was then measured at $510 \mathrm{~nm}$ using a UV-spectrophotometer (UV-1800, Shimadzu, Kyoto, Japan). TFC was calculated using a calibration curve expressed as quercetin equivalents.

\section{Total proanthocyanidin content}

The TPAC was determined as described by Boukhanouf et al. (2016) with some modifications. The extract was mixed with $2 \mathrm{~mL}$ of iron sulfate solution. The mixture was then incubated at $95^{\circ} \mathrm{C}$ for 15 minutes. The absorbance was determined at $540 \mathrm{~nm}$ using a UV-spectrophotometer (UV-1800, Shimadzu, Kyoto, Japan). The results were calculated and expressed as cyanidin equivalents.

\section{Trolox equivalent antioxidant capacity (TEAC) assay}

The TEAC was measured as described Siah et al. (2014) with a minor modification. For the measurements, the 2,2'azinobis (3-ethylbenzothiazoline-6-sulfonic acid) diammonium salt (ABTS) solution was diluted with $80 \%$ methanol then the absorbance measured at $734 \mathrm{~nm}$ using a UVspectrophotometer (UV-1800, Shimadzu, Kyoto, Japan). TEAC was calculated using a calibration curve of the Trolox standard curve.

\section{Ferric-reducing antioxidant power activity (FRAP) assay}

FRAP was assayed according to the method of Benzie and Strain (1996) with some modification. The FRAP reagent was prepared with $10 \mathrm{mM}$ of 2,4,6-tris(2-pyridyl)s-triazine solution in hydrochloric acid $(40 \mathrm{mM}), 20 \mathrm{mM}$ of iron chloride solution, and $0.3 \mathrm{M}$ acetate buffer ( $\mathrm{pH}$ 3.6) in the proportions of $1: 1: 10(\mathrm{v} / \mathrm{v})$. Fifty $\mu \mathrm{L}$ of each diluted ethanolic extract were mixed with $3 \mathrm{~mL}$ of freshly prepared FRAP reagent. The absorbance was measured at $593 \mathrm{~nm}$ using a UV-spectrophotometer (UV-1800, Shimadzu, Kyoto, Japan). The FRAP values were calculated and expressed as iron chloride/g dry weight of faba bean powder. 


\section{DPPH radical scavenging activity}

The DPPH radical scavenging activity was measured as described by Ryu et al. (2016). Each different concentrations of extract were added to $0.15 \mathrm{mM} \mathrm{DPPH}$, then after 30 minutes, the DPPH radicals remaining were quantified using a plate reader (Benchmark Plus; Bio-Rad, Hercules, CA, USA) at $517 \mathrm{~nm}$. The DPPH radical scavenging activity was calculated as follows:

DPPH radical scavenging activity $(\%)=\left(1-\mathrm{A}_{\mathrm{s}} / \mathrm{A}_{\mathrm{c}}\right) \times 100$

Where: $A_{s}$ : absorbance value with sample extract solution; $A_{c}$ : absorbance value without sample extract solution.

\section{UPLC-MS analysis}

Each sample extract was analyzed using a 1260 series high-performance liquid chromatography system, a 380 evaporative light scattering detector, and a 6130 quadrupole mass spectrometry system (Agilent Technologies Inc., Santa Clara, CA, USA) equipped with a Poroshell 120 SB-C18 column $(150 \mathrm{~mm} \times 4.6 \mathrm{~mm}$ internal diameter, 2.7 $\mu \mathrm{m}$ particle size; Agilent Technologies Inc., Santa Clara, CA, USA) with a compatible C18 guard column $(4 \mathrm{~mm} \times 3$ $\mathrm{mm}$ internal diameter, $3 \mu \mathrm{m}$ particle size; Phenomenex, Torrance, CA, USA). The mobile phase was composed of water $(\mathrm{A}, 0.05 \%$ formic acid) in acetonitrile $(\mathrm{B}, 0.05 \%$ formic acid). The following gradients were used: 0-3 minutes, $95 \% \mathrm{~A}$ and $5 \% \mathrm{~B}$; $3-28$ minutes, $100 \% \mathrm{~B}$; and $28-36$ minutes, $100 \% \mathrm{~B}$. The flow rate of the mobile phase was adjusted to $0.5 \mathrm{~mL} /$ minute, and the column temperature was set at $24^{\circ} \mathrm{C}$. The injection volume was 20 $\mu \mathrm{L}$. The mass parameters were as follows: drying gas pressure, $12.0 \mathrm{~L} /$ minute; positive and negative capillary voltage, $3000 \mathrm{~V}$; drying gas temperature, $350^{\circ} \mathrm{C}$; and nebulizer gas pressure, $35 \mathrm{psig}\left(\mathrm{Lb} / \mathrm{in}^{2}\right)$. The mass selective detector (MSD) signal settings in the positive/negative mode were as follows: mass range $(\mathrm{m} / \mathrm{z}), 100$ 1000; fragmentor, $70 \mathrm{~V}$; and scan mode.

\section{Data analysis}

All data were subjected to analysis of variance using the multiple comparisons method of SPSS version 12 (SPSS Inc., Chicago, IL, USA). The correlation analyses were based on Pearson's correlation coefficient. Any test results were determined to be statistically significant at $P<0.05$. When the treatment effect was significant, the means were separated using Duncan's multiple range tests.

\section{RESULTS}

\section{Phytochemical analysis}

The phytochemical contents (TTC, TFC, TPC, and TPAC) of the grain samples from each of the five faba bean genotypes are shown in Table 1 . The results revealed significant differences $(P<0.05)$ in the data between the different genotypes. The highest TTC was observed in the PI252004 and the lowest in the PI366039 genotypes. The TFC was highest in PI430715 (16.40 mg/g); followed by PI252004 (10.41 mg/g), PI614810 (10.01 mg/g), PI284345 $(9.98 \mathrm{mg} / \mathrm{g})$ and PI366039 $(8.18 \mathrm{mg} / \mathrm{g})$. The TPC obtained from the different genotypes also varied significantly, except for PI252004 and PI430715 which did not differ significantly. The TPC of all genotypes ranged from 24.82 to $29.71 \mathrm{mg} / \mathrm{g}$, the highest values being observed for the PI252004 and PI430715 genotypes. The PI252004 genotype had the highest TPAC and PI366039 the lowest.

\section{HPLC-MS analysis}

Representative HPLC-MS fingerprint chromatograms of the selected faba bean genotypes are shown in Table 2 and Supplementary Fig. S1. Twenty-two compounds were detected in the grain of the five faba bean genotypes. Fourteen compounds were detected in the PI252004 genotype; prodelphinidin ( $348.3 \mathrm{mg} / \mathrm{kg})$, epicatechin $(207.1$ $\mathrm{mg} / \mathrm{kg})$, epicatechin isomer $1(2.7 \mathrm{mg} / \mathrm{kg})$, epicatechin isomer $2(1.6 \mathrm{mg} / \mathrm{kg}), 6,8$-C-diglucosylapigenin $(6.0 \mathrm{mg} / \mathrm{kg})$, quercetin 3-O-rutinoside $(3.4 \mathrm{mg} / \mathrm{kg})$, quercetin $3-\mathrm{O}-$ rutinoside isomer $1(28.6 \mathrm{mg} / \mathrm{kg})$, quercetin 3-O-rutinoside isomer $2(1.8 \mathrm{mg} / \mathrm{kg})$, kaempferol-3-O-rhamnosylgalactoside $(9.9 \mathrm{mg} / \mathrm{kg}), \mathrm{kaempferol}-3$-rutinoside $(8.1 \mathrm{mg} / \mathrm{kg})$, apigenin 7-O-galactoside $(7.5 \mathrm{mg} / \mathrm{kg})$, procyanidin dimer $1(2.4$ $\mathrm{mg} / \mathrm{kg})$, procyanidin dimer $2(5.2 \mathrm{mg} / \mathrm{kg})$, and myricetin3-O-glucoside dimer $(9.5 \mathrm{mg} / \mathrm{kg})$; sixteen compounds in PI284345: prodelphinidin $(350.6 \mathrm{mg} / \mathrm{kg})$, epicatechin $(176.6 \mathrm{mg} / \mathrm{kg})$, epicatechin isomer $1(1.9 \mathrm{mg} / \mathrm{kg})$, epicatechin 
Table 2. Phenolic compound constituents $(\mathrm{mg} / \mathrm{kg})$ in selected faba bean genotypes by LC-MS.

\begin{tabular}{|c|c|c|c|c|c|c|c|c|c|}
\hline No. & $\begin{array}{l}\text { RT } \\
(\min )\end{array}$ & $\begin{array}{l}\lambda \max \\
(\mathrm{nm})\end{array}$ & $\begin{array}{l}{\mathrm{M}-\mathrm{H}^{+} /}^{\mathrm{M}-\mathrm{H}^{-}} \\
(\mathrm{m} / \mathrm{z})\end{array}$ & Tentative identification & PI252004 & PI284345 & PI366039 & PI614810 & PI430715 \\
\hline 1 & 7.64 & 277 & $-/ 593$ & Prodelphinidin ${ }^{\mathrm{y})}$ & $348.3 \mathrm{a}^{\mathrm{z})}$ & $350.6 \mathrm{a}$ & $353.2 \mathrm{a}$ & $350.9 a$ & $349.5 \mathrm{a}$ \\
\hline 2 & 10.77 & 279 & $291 / 289$ & Epicatechin $^{\mathrm{y})}$ & $207.1 \mathrm{a}$ & $176.6 b$ & $132.1 \mathrm{c}$ & $170.2 b$ & $204.4 a$ \\
\hline 3 & 10.84 & 279 & $291 / 289$ & Epicatechin isomer $1^{\mathrm{y}}$ & $2.7 b$ & $1.9 \mathrm{c}$ & $1.5 \mathrm{c}$ & $2.8 \mathrm{~b}$ & $11.4 \mathrm{a}$ \\
\hline 4 & 10.93 & 279 & $291 / 289$ & Epicatechin isomer $2^{\mathrm{y})}$ & $1.6 \mathrm{~b}$ & $0.6 \mathrm{c}$ & $-d$ & $1.1 \mathrm{bc}$ & $5.7 \mathrm{a}$ \\
\hline 5 & 11.09 & 334 & $595 / 593$ & 6,8-C-diglucosylapigenin ${ }^{\mathrm{x}}$ & $6.0 \mathrm{a}$ & $5.9 \mathrm{a}$ & $-c$ & $6.0 \mathrm{a}$ & $3.6 b$ \\
\hline 6 & 11.57 & 354 & $611 / 609$ & Quercetin 3-O-rutinoside ${ }^{\mathrm{y})}$ & $3.4 \mathrm{a}$ & $3.8 \mathrm{a}$ & $-b$ & $-b$ & $-b$ \\
\hline 7 & 11.58 & 354 & $611 / 609$ & Quercetin 3-O-rutinoside isomer1 ${ }^{\mathrm{y})}$ & $28.6 b$ & $15.2 \mathrm{c}$ & $13.4 \mathrm{c}$ & $28.1 \mathrm{~b}$ & $50.3 \mathrm{a}$ \\
\hline 8 & 11.67 & 354 & $611 / 609$ & Quercetin 3-O-rutinoside isomer2 $2^{\mathrm{y}}$ & $1.8 \mathrm{a}$ & $1.5 \mathrm{a}$ & $-b$ & $2.0 \mathrm{a}$ & $1.8 \mathrm{a}$ \\
\hline 9 & 11.89 & & - /797 & Gallotannin $^{\mathrm{x})}$ & $-\mathrm{c}$ & $10.1 \mathrm{a}$ & $-\mathrm{c}$ & $2.8 \mathrm{~b}$ & $-\mathrm{c}$ \\
\hline 10 & 12.12 & & $595 / 593$ & Kaempferol-3-O-rhamnosylgalactoside ${ }^{\mathrm{x})}$ & $9.9 \mathrm{a}$ & $-\mathrm{c}$ & $2.7 \mathrm{~b}$ & $-\mathrm{c}$ & $2.1 b$ \\
\hline 11 & 12.20 & & $595 / 593$ & Kaempferol-3-rutinoside ${ }^{\mathrm{x})}$ & $8.1 \mathrm{a}$ & $-b$ & $-b$ & $-b$ & $-b$ \\
\hline 12 & 12.20 & & $637 / 781$ & $\begin{array}{l}\text { Kaempferol } \\
\text { 3-O-acetyl-dirhamnosylhexoside }\end{array}$ & $-\mathrm{c}$ & $4.1 b$ & $2.1 b$ & $-\mathrm{c}$ & $10.6 \mathrm{a}$ \\
\hline 13 & 12.29 & & $637 / 781$ & $\begin{array}{l}\text { Kaempferol } \\
\text { 3-O-acetyl-dirhamnosylhexoside } \\
\text { dimer }^{\mathrm{x})}\end{array}$ & $-b$ & $-b$ & $-b$ & $-b$ & $0.8 \mathrm{a}$ \\
\hline 14 & 12.41 & & $653 / 651$ & $\begin{array}{l}\text { Luteolin-7-O-hexosyl-8-C-(6“-acetyl)- } \\
\text { hexoside }^{\mathrm{x})}\end{array}$ & $-\mathrm{c}$ & $7.0 \mathrm{a}$ & $-\mathrm{c}$ & $2.2 \mathrm{~b}$ & $-\mathrm{c}$ \\
\hline 15 & 12.49 & & $653 / 651$ & $\begin{array}{l}\text { Luteolin-7-O-hexosyl-8-C-(6“-acetyl)- } \\
\text { hexoside isomer }{ }^{\mathrm{x})}\end{array}$ & $-b$ & $0.4 \mathrm{a}$ & $-b$ & $-b$ & $-b$ \\
\hline 16 & 12.74 & 339 & $433 / 431$ & Apigenin 7-O-galactoside ${ }^{\mathrm{y})}$ & $7.5 b$ & $5.3 \mathrm{c}$ & $10.2 \mathrm{a}$ & $5.4 \mathrm{c}$ & $6.0 \mathrm{bc}$ \\
\hline 17 & 12.82 & 280 & $-/ 577$ & Procyanidin dimer $1^{\mathrm{y})}$ & $2.4 \mathrm{a}$ & $2.1 \mathrm{a}$ & $2.2 \mathrm{a}$ & $2.1 \mathrm{a}$ & $2.2 \mathrm{a}$ \\
\hline 18 & 12.90 & 280 & -1577 & Procyanidin $\operatorname{dimer} 2^{\mathrm{y})}$ & $5.2 \mathrm{a}$ & $2.3 \mathrm{c}$ & $1.8 \mathrm{c}$ & $3.8 \mathrm{~b}$ & $3.4 \mathrm{~b}$ \\
\hline 19 & 12.97 & & $-/ 635$ & 1,2,6-trigalloylglucose dimer ${ }^{x}$ & $-b$ & $-b$ & $-b$ & $0.4 \mathrm{a}$ & $-b$ \\
\hline 20 & 14.35 & 349 & $481 / 479$ & Myricetin-3-O-glucoside $\mathrm{e}^{\mathrm{y})}$ & $-c$ & $-\mathrm{c}$ & $-c$ & $82.9 \mathrm{a}$ & $2.9 \mathrm{~b}$ \\
\hline 21 & 14.37 & 349 & $481 / 479$ & Myricetin-3-O-glucoside dimer ${ }^{\mathrm{y})}$ & $9.5 \mathrm{a}$ & $6.8 \mathrm{~b}$ & $-e$ & $2.4 \mathrm{c}$ & $1.8 \mathrm{~d}$ \\
\hline 22 & 21.07 & & $595 / 593$ & Kaempferol-3-O-p-coumaroylhexoside ${ }^{\mathrm{x})}$ & $-b$ & $-b$ & $-b$ & $1.2 \mathrm{a}$ & $-\mathrm{b}$ \\
\hline
\end{tabular}

${ }^{z)}$ Different letters indicate a significant difference at the 0.05 probability level (Duncan's multiple range tests, $\mathrm{n}=3$ ).

${ }^{\mathrm{y})}$ Previously reported in faba bean grain (Baginsky et al. 2013). ${ }^{\mathrm{x})}$ Provisionally identified from UV and mass spectral data.

isomer $2(0.6 \mathrm{mg} / \mathrm{kg}), \quad 6,8$-C-diglucosylapigenin $(5.9$ $\mathrm{mg} / \mathrm{kg})$, quercetin 3-O-rutinoside $(3.8 \mathrm{mg} / \mathrm{kg})$, quercetin 3-O-rutinoside isomer $1(15.2 \mathrm{mg} / \mathrm{kg})$, quercetin 3-Orutinoside isomer $2(1.5 \mathrm{mg} / \mathrm{kg})$, gallotannin $(10.1 \mathrm{mg} / \mathrm{kg})$, kaempferol 3-O-acetyl-dirhamnosylhexoside $(4.1 \mathrm{mg} / \mathrm{kg})$, luteolin-7-O-hexosyl-8-C-(6"-acetyl)-hexoside (7.0 mg/kg), luteolin-7-O-hexosyl-8-C-(6“-acetyl)-hexoside isomer (0.4 $\mathrm{mg} / \mathrm{kg}$ ), apigenin $7-\mathrm{O}$-galactoside $(5.3 \mathrm{mg} / \mathrm{kg})$, procyanidin dimer $1(2.1 \mathrm{mg} / \mathrm{kg})$, procyanidin dimer $2(2.3$ $\mathrm{mg} / \mathrm{kg})$, and myricetin-3-O-glucoside dimer $(6.8 \mathrm{mg} / \mathrm{kg})$; nine compounds in PI366039: prodelphinidin (353.2 $\mathrm{mg} / \mathrm{kg})$, epicatechin $(132.1 \mathrm{mg} / \mathrm{kg})$, epicatechin isomer 1 $(1.5 \mathrm{mg} / \mathrm{kg})$, quercetin 3-O-rutinoside isomer 1 (13.4 $\mathrm{mg} / \mathrm{kg}$ ), kaempferol-3-O-rhamnosylgalactoside (2.7 mg/kg), kaempferol 3-O-acetyl-dirhamnosylhexoside $(2.1 \mathrm{mg} / \mathrm{kg})$, apigenin $7-\mathrm{O}$-galactoside $(10.2 \mathrm{mg} / \mathrm{kg})$, procyanidin dimer1 $(2.2 \mathrm{mg} / \mathrm{kg})$, and procyanidin dimer $2(1.8 \mathrm{mg} / \mathrm{kg})$; sixteen compounds in PI614810: prodelphinidin (350.9 $\mathrm{mg} / \mathrm{kg})$, epicatechin $(170.2 \mathrm{mg} / \mathrm{kg})$, epicatechin isomer 1 $(2.8 \mathrm{mg} / \mathrm{kg})$, epicatechin isomer $2(1.1 \mathrm{mg} / \mathrm{kg}), 6,8-\mathrm{C}$ diglucosylapigenin $(6.0 \mathrm{mg} / \mathrm{kg})$, quercetin 3-O-rutinoside isomer $1(28.1 \mathrm{mg} / \mathrm{kg})$, quercetin 3-O-rutinoside isomer 2 $(2.0 \mathrm{mg} / \mathrm{kg})$, gallotannin $(2.8 \mathrm{mg} / \mathrm{kg})$, luteolin-7-O-hexosyl8-C-(6"-acetyl)-hexoside (2.2 mg/kg), apigenin 7-Ogalactoside $(5.4 \mathrm{mg} / \mathrm{kg})$, procyanidin dimer $1(2.1 \mathrm{mg} / \mathrm{kg})$, procyanidin dimer $2(3.8 \mathrm{mg} / \mathrm{kg}), 1,2,6$-trigalloylglucose 
dimer $(0.4 \mathrm{mg} / \mathrm{kg})$, myricetin-3-O-glucoside $(82.9 \mathrm{mg} / \mathrm{kg})$, myricetin-3-O-glucoside dimer $(2.4 \mathrm{mg} / \mathrm{kg})$, and kaempferol3-O-p-coumaroylhexoside $(1.2 \mathrm{mg} / \mathrm{kg})$; and fifteen compounds in PI430715: prodelphinidin $(349.5 \mathrm{mg} / \mathrm{kg})$, epicatechin $(204.4 \mathrm{mg} / \mathrm{kg})$, epicatechin isomer $1(11.4 \mathrm{mg} / \mathrm{kg})$, epicatechin isomer $2(5.7 \mathrm{mg} / \mathrm{kg}), 6,8$-C-diglucosylapigenin $(3.6 \mathrm{mg} / \mathrm{kg})$, quercetin 3-O-rutinoside isomer $1(50.3 \mathrm{mg} / \mathrm{kg})$, quercetin 3-O-rutinoside isomer $2(1.8 \mathrm{mg} / \mathrm{kg})$, Kaempferol3-O-rhamnosylgalactoside $(2.1 \mathrm{mg} / \mathrm{kg}) \mathrm{kaempferol} 3-\mathrm{O}$ acetyl-dirhamnosylhexoside $(10.6 \mathrm{mg} / \mathrm{kg})$, kaempferol 3-O-acetyl-dirhamnosylhexoside dimer $(0.8 \mathrm{mg} / \mathrm{kg})$, apigenin-7-O-galactoside $(6.0 \mathrm{mg} / \mathrm{kg})$, procyanidin dimer $1(2.2 \mathrm{mg} / \mathrm{kg})$, procyanidin dimer $2(3.4 \mathrm{mg} / \mathrm{kg})$, myricetin3-O-glucoside $(2.9 \mathrm{mg} / \mathrm{kg})$, and myricetin-3-O-glucoside

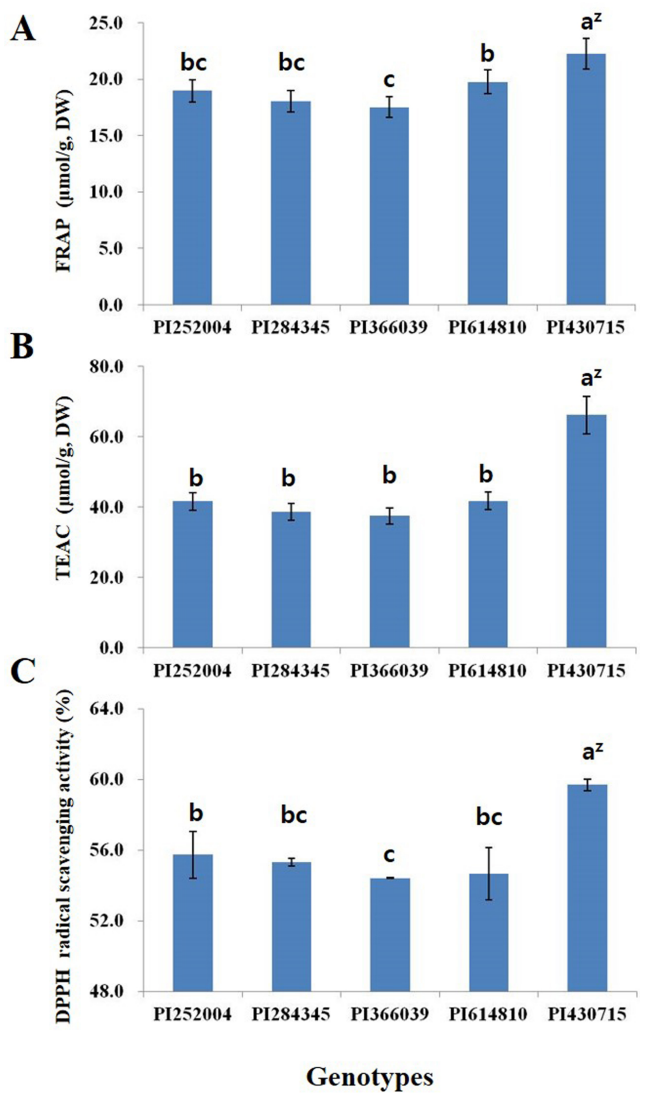

Fig. 2. Antioxidant activity of five selected faba bean genotypes bred in Korea. (A) Ferric-reducing antioxidant power (FRAP) activity, (B) Trolox equivalent antioxidant capacity (TEAC), (C) DPPH radical scavenging activity. ${ }^{\mathrm{z}}$ Different letters indicate a significant difference at the 0.05 probability level (Duncan's multiple range tests, $\mathrm{n}=3$ ). dimer $(1.8 \mathrm{mg} / \mathrm{kg})$.

\section{Antioxidant activities}

The results of analyzing the antioxidant activity of the five selected faba bean genotypes are shown in Fig. 2. The FRAP activity of all the genotypes ranged from 17.5 to 22.3 $\mu \mathrm{mol} / \mathrm{g}$ with the highest activity being observed in the PI430715 genotype. This genotype also showed the highest TEAC activity, but there were no significant differences in TEAC activity between the PI252004, PI284345, PI366039 and PI614810 genotypes. The PI430715 genotype also exhibited the greatest DPPH radical scavenging activity followed by the PI252004, PI284345, PI614810 and PI366039 genotypes.

\section{DISCUSSION}

Faba bean seeds are rich in many functional components such as phenolic and flavonoid compounds (Baginsky et al. 2013). However, there have been few studies on the phenolic and flavonoid contents of faba beans grown in Korea. The results of the present study have revealed the presence of phytochemical compounds in the grain of selected faba beans with a high yield, and high contents of L-dopa and linolenic acid. These genotypes could potentially be used in faba bean breeding programs.

Tannins are an important nutritive component of faba bean for use as food and feed (Shazali 1990; Goyoaga et al. 2008; Kosinska et al. 2011) and are present mainly in the seed coat (Papadopoulos et al. 1985; Shazali 1990). It was found that faba beans with black seed coats contained lower tannin content than those with brown and purple seed coats. Similarly, Shazali (1990) reported that faba beans with a black seed coat exhibited a lower tannin content than those with dark brown, brown, light brown or white seed coats. Papadopoulos et al. (1985) reported that faba beans with a white seed coat were tannin-free but the darker the color, the greater the tannin content in the faba bean. This variability in faba bean tannin content has been assumed to be influenced by the genotype and by environmental factors (Kosinska et al. 2011; Baginsky et al. 2013). Previously, the predominant pigment in beige, black, 
brown, green, red, and violet faba bean seeds was found to be myricetin and anthocyanin (Nozzolillo et al. 1989). Our results suggest that seed coat color is not a good indicator of the tannin content of faba beans.

We observed significant differences in TPC and TFC between the different faba bean genotypes. The TFC and TPC in the seed of the PI430715 genotype were higher than those from the other genotypes. The TFC and TPC of all genotypes were also higher than those reported in the grain of faba beans by Boukhanouf et al. (2016), TFC $(0.167 \mathrm{mg}$ quercetin equivalent/g) and TPC (12 mg gallic acid equivalent $/ \mathrm{g}$ ). These differences may be related to the different genotypes and the analytical method (gallic acid equivalent) used. Ryu et al. (2017) have also reported that the PI430715 genotype is potentially the most suitable material for helping treat Parkinson's disease because of its high levels of L-DOPA. L-DOPA, a phenolic compound with two hydroxyl groups, has been reported as the predominant secondary metabolite detected in faba beans (Shetty et al. 2003; Oomah et al. 2011; Hu et al. 2015). In additions, the PI430715 genotype was selected on the basis of high seed and biomass production after spring sowing in early March (Ryu et al. 2017). Our results suggest that PI430715 is potentially the most appropriate of the five faba bean genotypes for improving health benefits because of its high levels of TPC and TFC.

In a previous study, proanthocyanidins have been shown to provide effective antioxidant activity in faba bean (Boukhanouf et al. 2016). These condensed tannins (proanthocyanidins) are oligomers or polymers of flavan-3-ols linked by carbon-carbon bonds (Shazali 1990; Kosinska et al. 2011; Baginsky et al. 2013). In the present study, the TPAC ranged from 0.162 (PI366039) to 0.271 $\mathrm{mg} / \mathrm{g}$ (PI252004) with an average of $0.207 \mathrm{mg} / \mathrm{g}$. These results were similar to those reported by Siah et al. (2014) for faba beans $(0.13-0.23 \mathrm{mg} / \mathrm{g})$. The most notable of the results of the present study were the high TPAC in the PI252004 and PI430715 genotypes. There was also a significant difference between TPC and TPAC for PI284345, which may have distorted the spectrophotometric analysis of the faba bean (Baginsky et al. 2013).

The phenolic compounds in faba beans, phenolic acids, catechin, flavonols, proanthocyanidins and anthocyanins, exhibit a great range of different structures (Siah et al. 2014). In the present study, the predominant compounds identified by LC-MS analysis in all faba bean genotypes were proanthocyanidins (prodelphinidin and catechin). Proanthocyanidins, phenolic compounds, are widely distributed in legume crops. Previous studies have reported that proanthocyanidins were the main phenolic compound in legume crops such as faba bean (Baginsky et al. 2013), soybean (Takahashi et al. 2005; Ito et al. 2013) and lentil bean (Xu and Chang 2007). Flavonols and flavones are important compounds because of their strongly antioxidative activity (Majewska et al. 2011). The predominant flavonols and flavones in the selected faba bean genotypes were myricetin, quercetin, apigenin, kaempferol, and luteolin-free aglycones or glycosides. This agreed with other studies on faba beans where the flavonols were mainly myricetin, kaempferol, and quercetin derivatives (Nozzolillo et al. 1989; Biginsky et al. 2013). The concentration and presence of phenolic compounds in crops is influenced by genetic and environment factors (Baginsky et al. 2013; Ryu et al. 2016). In the present study, all the genotypes were grown in the same field during the same season, so any differences observed in the

Table 3. Correlation analysis between phytochemical content and antioxidant activity in faba bean genotypes.

\begin{tabular}{lcc}
\hline \multicolumn{1}{c}{ Trait } & $P$-value & $\mathrm{R}^{2}$ \\
\hline \hline Total flavonoid content and FRAP activity & $*$ & 0.939 \\
Total flavonoid content and TEAC activity & $* *$ & 0.984 \\
Total flavonoid content and DPPH radical scavenging activity & $*$ & 0.986 \\
FRAP activity and TEAC activity & $*$ & 0.941 \\
FRAP activity and DPPH radical scavenging activity & $* *$ & 0.882 \\
TEAC activity and DPPH radical scavenging activity & 0.977 \\
\hline
\end{tabular}

*Significant at the 0.05 probability level, **Significant at the 0.01 probability level. 
levels of phenolic compounds between the genotypes probably reflected genotypic variation. Further studies that take account annual and environmental variation would be needed to quantify their influence on the phenolic composition of these genotypes.

The phenolic and flavonoid compounds are responsible for the antioxidant activities of plant materials (Majewska et al. 2011; Ryu et al. 2016). The Pearson's correlation coefficients listed in Table 3 provide an indication of the strength of the relationship between the contents of these compounds and the different types of measured antioxidant activity. The TFC was correlated with FRAP activity $(P \leq 0.05)$, TEAC activity $(P \leq 0.01)$ and DPPH radical scavenging activity $(P \leq 0.01)$, the FRAP activity with TEAC activity and DPPH radical scavenging activity $(P \leq 0.05)$ and the TEAC activity with DPPH radical scavenging activity $(P \leq 0.01)$. Similarly, Boukhanouf et al. (2016) have reported that the DPPH radical scavenging activity and oxygen uptake inhibition activity of faba bean were highly correlated with TPC and TFC. Strong correlations between antioxidant activity and total flavonoid or total phenolic contents of faba beans have also been reported elsewhere (Adsule and Akpapunam 1996; Baginsky et al. 2013; Siah et al. 2014).

The use of faba beans as materials providing antioxidant activity may increase demand for them. In addition, breeding to achieve higher concentrations of functional compounds in crops is important for improving human health (Ryu et al. 2017). Our results suggest that the PI430715 genotype is the most suitable source for food and feed because it contained higher levels of functional compounds with greater antioxidant activity. The PI430715 genotype also exhibited higher levels of epicatechin isomer, quercetin 3-O-rutinoside isomer and kaempferol 3-O-acetyl-dirhamnosylhexoside than the other genotypes.

These results will be useful to help identify antioxidant compounds with enhanced qualities and potentially greater health benefits when faba beans are included in the human diet.

\section{ACKNOWLEDGEMENTS}

This work was supported by Radiation Technology R\&D program (NRF-2017M2A2A6A05018538) through the National Research Foundation of Korea funded by the Ministry of Science and ICT.

\section{REFERENCES}

Adsule RN, Akpapunam M. 1996. Faba bean (Vicia faba L.). pp. 197-202. In: E. Nwokolo, J. Smartt (eds.). Food and feed from legumes and oilseeds. Springer, Boston, MA, U.S.A.

Agung S, McDonald GK. 1998. Effects of seed size and maturity on the growth and yield of faba bean (Vicia faba L.). Aust. J. Agr. Res. 49: 79-88.

Baginsky C, Pena-Neira A, Caceres A, Hernandez T, Estrella I, Morales H, et al. 2013. Phenolic compound composition in immature seeds of fava bean (Vicia faba L.) varieties cultivated in Chile. J. Food Compost. Anal. 31: 1-6.

Benzie IFF, Strain JJ. 1996. The ferric reducing ability of plasma (FRAP) as a measure of "antioxidant power": The FRAP assay. Analytical Biochem. 239: 70-76.

Boukhanouf S, Louaileche H, Perrin D. 2016. Phytochemical content and in vitro antioxidant activity of faba bean (Vicia faba L.) as affected by maturity stage and cooking practice. International Food Research Journal 23: 954-961.

Crepon K, Marget P, Peyronnt C, Carrouee B, Arese P, Duc G. 2010. Nutritional value of faba bean (Vicia faba L.) seeds for feed and food. Field Crops Res. 115: 329-339.

Chaieb N, Gonzalez JL, Lopez-Mesas M, Bouslama M, Valiente M. 2011. Polyphenols content and antioxidant capacity of thirteen faba bean (Vicia faba L.) genotypes cultivated in Tunisia. Food Res. Inter. 44: 970-977.

Goyoaga C, Burbano C, Cuadrado C, Varela A, Guillamon E, Pedrosa MM, et al. 2008. Content and distribution of vicine, convicine and L-DOPA during germination and seedling growth of two Vicia faba L. varieties. Eur. Food Res. Technol. 227: 1537-1542.

Gunawardena CK, Zijlstra RT, Beltranena E. 2010. Characterization of the nutritional value of air-classified protein and starch fractions of field pea and zero-tannin 
faba bean in grower pigs. J. Animal. Sci. 88: 660-670.

Hu J, Kwon SJ, Park JJ, Landry E, Mattinson DS, Gang DR. 2015. LC-MS determination of L-DOPA concentration in the leaf and flower tissues of six faba bean (Vicia faba L.) lines with common and rare flower colors. Functional Foods in Health and Disease 5: 243-250.

Kosinska A, Karamac M, Penkacik K, Urbalewicz A, Amarowicz R. 2011. Interactions between tannins and proteins isolated from broad bean seeds (Vicia faba Major) yield soluble and non-soluble complexes. Eur. Food Res. Technol. 233: 213-222.

Ito C, Oki T, Yoshida T, Nanba F, Yamada K, Toda T. 2013. Characterisation of proanthocyanidins from black soybeans: Isolation and characterisation of proanthocyanidin oligomers from black soybean seed coats. Food Chem. 141: 2507-2512.

Majewska M, Skrzycki M, Podsiad M, Czeczot H. 2011. Evaluation of antioxidant potential of flavonoids: an in vitro study. Acta Pol. Pharm. 68: 611-615.

Nozzolillo C, Ricciardi L, Lattanzio V. 1989. Flavonoid constituents of seed coats of Vicia faba (Fabaceae) in relation to genetic control of their color. Can. J. Bot. 67: 1600-1604.

Oomah BD, Luc G, Leprelle C, Drover JCG, Harrison JE, Olson M. 2011. Phenolics, phytic acid, and phytase in Canadian-grown low tannin faba bean (Vicia faba L.) genotypes. J. Agric. Food Chem. 59: 3763-3771.

Papadopoulos CH, Tsaflaris AS, Roupakias DG. 1985. Correlation between tannin content and testa colour in faba beans (Vicia faba L.). Fabis 13: 38-40.

Price ML, Scoyoc SV, Butler LG. 1978. Critical evaluation of vanillin reaction as an assay for tannin in sorghum grain. J. Agric. Food Chem. 26: 1214-1218.
Ryu J, Kim DG, Lee MK, Kim JM, Hong MJ, Kang KY, et al. 2017. Fatty acid composition, isoflavone and L-3,4dihydroxyphenylalanine (L-dopa) contents in different parts of faba bean (Vicia faba) genotypes. Plant Breed. Biotech. 5: 314-324.

Ryu J, Kwon SJ, Jo YD, Jin CH, Nam BM, Lee SY, et al. 2016. Comparison of phytochemicals and antioxidant activity in blackberry (Rubus fruticosus L.) fruits of mutant lines at the different harvest time. Plant Breed. Biotech. 4: 242-251.

Shazali MEH. 1990. Faba bean (Vicia faba L.) seed coat colour tannin content and susceptibility to bruchids. Int. J. Trop. Insect. Sci. 11:855-859.

Shetty P, Atallah MT, Shetty K. 2003. Stimulation of total phenolics, L-DOPA and antioxidant activity through proline-linked pentose phosphate pathway in response to proline and its analogue in germinating fava beans (Vicia faba). Process Biochem. 38: 1707-1717.

Siah S, Konczak I, Wood JA, Agboola S, Blanchard CL. 2014. Effects of roasting on phenolic composition and in vitro antioxidant capacity of Australian grown faba beans (Vicia faba L.). Plant Foods Hum. Nutr. 69: 85-91.

Takahashi R, Ohmori R. Kiyose C, Momiyama Y, Ohsuzu F, Kondo K. 2005. Antioxidant activities of black and yellow soybeans against low density lipoprotein oxidation. J. Agric. Food Chem. 53: 4578-4582.

Xu BJ, Chang SK. 2007. A comparative study on phenolic profiles and antioxidant activities of legumes as affected by extraction solvents. J. Food Sci. 72: 159-166.

Zhishen J, Mengcheng T, Jianming W. 1999. The determination of flavonoid contents in mulberry and their scavenging effects on superoxide radicals. Food Chem. 64: 555-559. 